DOI https://doi.org/10.18551/rjoas.2020-09.06

\title{
POTENTIAL FOOD SAFETY RISKS IN THE PROCESSING OF GRILLED FISH IN TEGAL REGENCY OF INDONESIA
}

\author{
Fatahuddin Fatahuddin* \\ Graduate Program, Politeknik AUP, Jakarta, Indonesia \\ Aef Permadi, Eko Irianto Hari \\ Fishery Product Processing Industry, Politeknik AUP, Jakarta, Indonesia \\ *E-mail: fatahudin316@gmail.com
}

\begin{abstract}
Food safety is something that must be fulfilled by a product that is produced. In processing the product, it is always accompanied by the risks posed by matters related to the process. The processing of grilled fish contains 11 risk events that can cause it to be unsafe for consumption, namely: 1) Handling method at Fishing Port, 2) Handling method for suppliers, 3) Loading method on vehicles, 4) Types of vehicles used, 5) Weeding method, 6) Tools used in weeding, 7) Water used, 8) Washing method, 9) Draining method, 10) Grilling method, 11) Tools used, 12) Storage method. Of the 12 risk events, there are 3 events that have a high RPN value, namely: grilling, draining and storage methods that must be repaired immediately so that the resulting product is safe for consumption.
\end{abstract}

\section{KEY WORDS}

Grilled fish, process flow, risk, FMEA.

Fishery business activities from the landing site, fish handling to fish processing generally always produce waste, ranging from liquid and solid waste. All this results in environmental pollution such as air pollution (in the form of odors) due to the nature of fish which is prone to decay.

According to Hariyadi (2016), food security in Indonesia has unique conditions, and shows that there are multiple challenges to be solved. The first challenge for food safety arises as a result of domestic food safety conditions triggered by low sanitation and hygiene practices by Food Small and Medium Industry. The second challenge for food safety arises from the side of international trade, particularly in connection with the emergence of various new contaminants (emerging contaminants), increasingly stringent international food safety standards, food falsification, and the threat of intentional contamination.

Risk can be defined in various ways. For example, risk can be defined as an adverse event. Another definition that is often used for investment analysis is the possibility that the results obtained deviate from the expected. Standard deviation is a statistical tool that can be used to measure deviation, therefore the standard deviation can be used to measure risk. Another measurement is using probability (M. Hanafi, 2014).

The main principles and procedures for food safety are the prevention and anticipation of physical contamination such as foreign matter, chemical contamination such as the smell of kerosene, etc., products of various possibilities before the product reaches consumers. In the food supply chain, this food safety procedure applies to all stages without exception, based on the level of risk of pollution (low risk to high risk). If the risk of pollution is higher, the preventive procedures that are applied will also be even more stringent. Food safety programs and procedures refer to regulations implemented by the government (Ministry of Health/ Indonesian Food and Drug Authority (BPOM), Institute for the Assessment of Food, Drugs and Cosmetics of the Indonesian Ulema Council (LPOM MUI)) and by international institutions, such as CODEX Alimentarius, USFDA, ISO 22000, HACCP and others.

Smoking using the traditional method by direct roasting is known as grilling, which has several weaknesses, namely the quality of the resulting product is inconsistent, the 
accumulation of harmful compounds such as tar and benzopirene in the product. In addition, it causes air pollution, and smoking efficiency is difficult to control (Suroso et al., 2018).

FMEA is a good analytical technique used by companies to prevent and eliminate defects that arise by looking at the cause and effect relationship of defects, and looking for solutions with appropriate actions. FMEA is carried out as a supporting method of risk assessment studies and identification of potential hazards (Dudek \& Burlikowska, 2011), which is quoted from Puspitasari, et.al, (2018). This method is appropriate to use in finding the right solution in solving problems from the company.

\section{METHODS OF RESEARCH}

Time and Location of Research. This research was conducted at the center of grilled fish processing in Tegal Regency. Implementation time was from September to December 2019. Data collection in this study was carried out by means of observations, questionnaires and interviews. Sources of information used were grilled fish processing actors.

According to Wahyuni et.al, (2018) data processing to measure the level of food safety risk in the supply chain uses the FMEA (Failure Mode and Effect Analysis) method. The steps carried out in the FMEA method are as follows:

- Identifying risk events in the fish supply chain process;

- Determining the likelihood, impact and detection value for each risk event;

- Determining the risk score and RPN;

- Developing a critical (important) risk mitigation plan;

- Conducting evaluation of risk scores and RPN based on plans for risk response;

- To be able to measure risk with FMEA, it is necessary to provide a likelihood score, an impact score, and a detection score. The following is a table of scoring on likelihood, impact and detection.

Table 1 - Likelihood Scoring

\begin{tabular}{|l|l|}
\hline Likelihood Score & The chance or likelihood of the occurence of a risky event \\
\hline 9 or 10 & Almost certainly it will occur, the chance is around $90-100 \%$ \\
\hline 7 or 8 & Will occur, the chance is around $70-80 \%$ \\
\hline 5 or 6 & May or may not occur, the chance is around $50 \%$ \\
\hline 3 or 4 & Very likely will not occur, the chance is around $30-40 \%$ \\
\hline 1 or 2 & Almost certainly will not occur, the chance is around $10-20 \%$ \\
\hline
\end{tabular}

Source: Gasperz, 2012.

Table 2 - Impact Scoring

\begin{tabular}{|c|c|c|c|}
\hline \multirow{2}{*}{$\begin{array}{l}\text { Impact } \\
\text { Score (I) }\end{array}$} & \multicolumn{3}{|l|}{ Influence on aspects } \\
\hline & Schedule & Cost & Impact \\
\hline 9 or 10 & $\begin{array}{l}\text { Has a major impact on } \\
\text { milestones and is greater } \\
\text { than } 20 \% \text { of critical paths }\end{array}$ & $\begin{array}{l}\text { Increase the total } \\
\text { cost by more than } \\
20 \%\end{array}$ & $\begin{array}{l}\text { Impact on the final product or an item can no } \\
\text { longer be used. }\end{array}$ \\
\hline 7 or 8 & $\begin{array}{l}\text { Has a major impact on } \\
\text { milestones and about } 10 \% \text { - } \\
20 \% \text { to critical paths }\end{array}$ & $\begin{array}{l}\text { Increase the total } \\
\text { cost by about } 10 \%- \\
20 \%\end{array}$ & $\begin{array}{l}\text { Impact on the final product or an item can no } \\
\text { longer be used. }\end{array}$ \\
\hline 5 or 6 & $\begin{array}{l}\text { Affects about } 5 \%-10 \% \text { on } \\
\text { critical path }\end{array}$ & $\begin{array}{l}\text { Increase the total } \\
\text { project cost by } \\
\text { about } 5 \%-10 \%\end{array}$ & $\begin{array}{l}\text { Impact on the final product or an item that } \\
\text { requires client or customer approval whether to } \\
\text { accept the product or not. }\end{array}$ \\
\hline 3 or 4 & $\begin{array}{l}\text { Less than } 5 \% \text { effect on } \\
\text { critical path }\end{array}$ & $\begin{array}{ll}\text { Increase } & \text { total } \\
\text { project cost } & \text { less } \\
\text { than } 5 \% & \end{array}$ & $\begin{array}{l}\text { Impact on the final product or an item that } \\
\text { requires sufficient approval from the internal } \\
\text { company to deliver the product to the client or } \\
\text { customer. }\end{array}$ \\
\hline 1 or 2 & $\begin{array}{l}\text { Has no effect on the critical } \\
\text { path }\end{array}$ & $\begin{array}{l}\text { Does not increase } \\
\text { the total project } \\
\text { cost }\end{array}$ & Has no impact on the final product or item. \\
\hline
\end{tabular}

Source: Gasperz, 2012. 
Table 3 - Detection Scoring

\begin{tabular}{|l|l|}
\hline Detection Score & $\begin{array}{l}\text { The ability of the detection method to risk } \\
\text { No detection method or existing detection methods are unable to provide sufficient time to } \\
\text { implement the contingency plan. }\end{array}$ \\
\hline 7 or 8 & $\begin{array}{l}\text { The detection method is not proven or reliable, or the effectiveness of the detection method is } \\
\text { unknown for timely detection. }\end{array}$ \\
\hline 5 or 6 & The detection method has an average level of effectiveness (medium). \\
\hline 3 or 4 & $\begin{array}{l}\text { The detection method has a high level of effectiveness. } \\
\text { sufficient time to implement the contingency plan. }\end{array}$ \\
\hline 1 or 2 &
\end{tabular}

Source: Gasperz, 2012.

The next stage was processing risk data with FMEA, then compiling the classification of risk scores and RPN values from the largest to the smallest values. The largest values are priorities that must be addressed immediately (Budi, et.al, 2018). After that, a Focus Group Discussion (FGD) was carried out by involving competent people in terms of food safety risks. The purpose of the FGD is to validate the results of the questionnaire and obtain more detailed information (Anggrahini, et.al, 2017).

\section{RESULTS AND DISCUSSION}

Processed grilled fish consisted of various kinds of sea fish including: decapterus, tuna, and hagfish. The processing process can be seen in the image below:

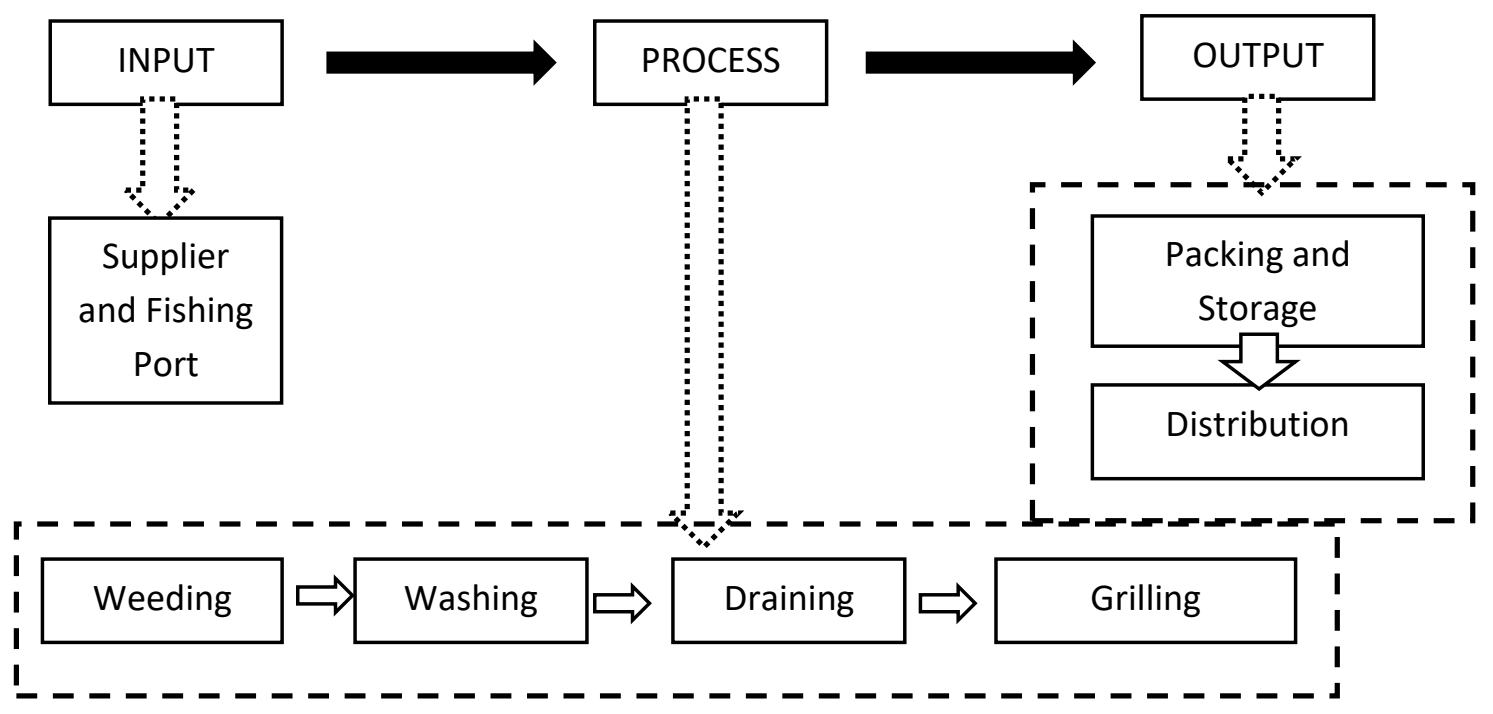

Figure 1 - Process Flow of Grilled Fish Production

The stages in the grilled fish processing process are as follows:

1. Input, this stage was the stage of receiving raw materials obtained from suppliers and through the auction process at the Fishing Port.

2. Process, this stage was divided into 4 (four) stages of activity in the grilled fish processing, namely:

- Weeding, in this stage the cleaning and filleting of fish was carried out which aimed to remove dirt and stomach contents;

- Washing was carried out to remove dirt that was still attached to the fish's body and the remaining blood that was still in the stomach contents;

- Then proceed with draining so that the surface of the fish body was dry;

- Grilling was done for about 3-5 minutes on a frying coal using a wood grill.

3. Output was the last stage in the grilled fish processing process. 
- After the cooked fish were arranged in a bamboo basket, packing was not done one by one. Storage was carried out after all the fish have been grilled. Then it was stored for 1 night or approximately 14 hours in freezing temperatures;

- Distribution was carried out to traditional markets around Tegal Regency, Tegal City and Pemalang Regency.

The results showed that there were several events that pose a risk to food safety.

Table 4 - Risk events in grilled fish processing

\begin{tabular}{|l|l|l|}
\hline Process flow & Risk Event & Impact \\
\hline \multirow{4}{*}{ Input } & Handling method at Fishing Port & Physical damage to fish, residual formaldehyde, histamine \\
& Handling method for suppliers & content, bacterial contamination. \\
\cline { 2 - 2 } & Loading method on vehicles & \\
\cline { 2 - 2 } & Type of vehicles used & \\
\hline \multirow{4}{*}{ Process } & Weeding method & \multirow{3}{*}{ Bacterial contamination from the work equipment or materials } \\
\cline { 2 - 2 } & Tools used in weeding & \\
\cline { 2 - 2 } & Water used & \\
\cline { 2 - 2 } & Washing method & \\
\cline { 2 - 2 } & Draining method & \\
\cline { 2 - 2 } & Grilling method & \\
\hline \multirow{2}{*}{ Output } & Tools used & \\
\cline { 2 - 3 } & Storage method & \\
\hline
\end{tabular}

Next, risk measurement was carried out after the various risk events were identified. Measurement of risk is an important stage because it can be used as an evaluation material in processing activities to what extent food safety risk control can be controlled.

The results obtained from risk measurement using FMEA risk are as follows:

Table 5 - Risk Data Processing with FMEA

\begin{tabular}{|l|l|l|l|l|l|l|}
\hline Process Flow & Risk Event & Likelihood & Impact & Risk Score & Detection & RPN \\
\hline \multirow{4}{*}{ Input } & Handling method at Fishing Port & 7 & 7 & 49 & 3 & 147 \\
\cline { 2 - 7 } & Handling method for suppliers & 6 & 6 & 36 & 3 & 108 \\
\cline { 2 - 7 } & Loading method on vehicles & 6 & 6 & 36 & 3 & 108 \\
\cline { 2 - 7 } & Type of vehicles used & 6 & 7 & 42 & 3 & 126 \\
\hline \multirow{5}{*}{ Process } & Weeding method & 6 & 7 & 42 & 3 & 126 \\
\cline { 2 - 7 } & Tools used in weeding & 6 & 6 & 36 & 3 & 108 \\
\cline { 2 - 7 } & Water used & 5 & 6 & 30 & 6 & 180 \\
\cline { 2 - 7 } & Washing method & 7 & 7 & 49 & 6 & 180 \\
\cline { 2 - 7 } & Draining method & 8 & 8 & 64 & 6 & 384 \\
\cline { 2 - 7 } & Grilling method & 6 & 6 & 36 & 3 & 108 \\
\hline \multirow{3}{*}{ Output } & Tools used for packing & Storage method & & 64 & 3 & 192 \\
\cline { 2 - 7 } & & & & 6 & 6 & 3 \\
\hline
\end{tabular}

Next, the risk event score ranking was carried out in the grilled fish processing process as in the table below:

Table 6 - Risk Event Score Ranking

\begin{tabular}{|l|c|}
\hline \multicolumn{1}{|c|}{ Risk Event } & Risk Score \\
\hline Grilling method (A) & 64 \\
\hline Storage method (B) & 64 \\
\hline Draining method (C) & 49 \\
\hline Handling method at Fishing Port (D) & 49 \\
\hline Type of vehicles used (E) & 42 \\
\hline Weeding method (F) & 42 \\
\hline Handling method for suppliers (G) & 36 \\
\hline Loading method on vehicles (H) & 36 \\
\hline Tools used in weeding (I) & 36 \\
\hline Tools used for packing (J) & 36 \\
\hline Water used (K) & 30 \\
\hline Washing method (L) & 30 \\
\hline
\end{tabular}


The risk ranking in table 6 can be illustrated in the Pareto diagram below.

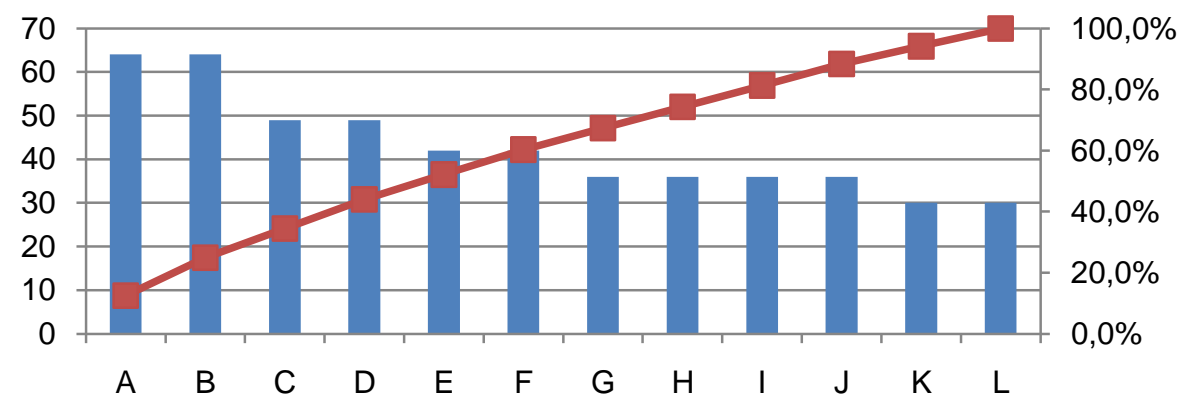

Figure 2 - Diagram of Pareto of Risk

The pareto diagram illustrates that there are 6 (six) events that have a risk of affecting the safety of grilled fish products, namely: grilling method, storage method, draining method, handling method at Fishing Port, type of vehicles used, weeding method.

Table 7 - RPN Value Ranking

\begin{tabular}{|l|c|}
\hline \multicolumn{1}{|c|}{ Risk Event } & RPN Score \\
\hline Grilling method (a) & 384 \\
\hline Draining method (b) & 294 \\
\hline Storage method (c) & 192 \\
\hline Water used (d) & 180 \\
\hline Washing method (e) & 180 \\
\hline Handling method at Fishing Port (f) & 147 \\
\hline Type of vehicles used (g) & 126 \\
\hline Weeding method (h) & 126 \\
\hline Handling method for suppliers (i) & 108 \\
\hline Loading method on vehicles (j) & 108 \\
\hline Tools used in weeding (k) & 108 \\
\hline Tools used for packing (l) & 108 \\
\hline
\end{tabular}

The RPN value above can be illustrated by the Pareto diagram below:

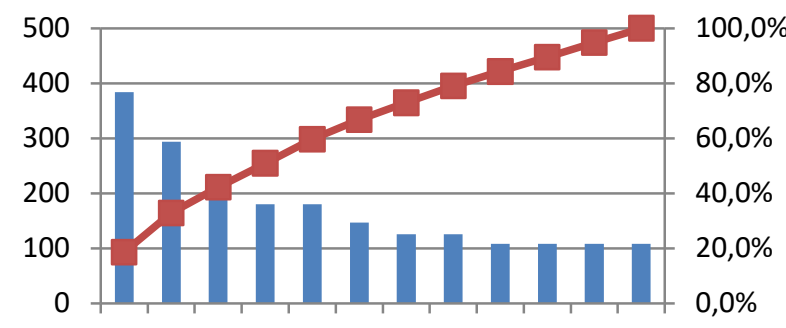

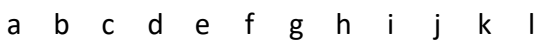

Figure 3 - Diagram of Pareto of RPN

Figure 3 illustrates that there are 3 events that have the highest RPN value, namely: grilling method, draining method and storage method. The grilling method has the highest RPN value because it greatly affects the final product produced.

\section{CONCLUSION AND RECOMMENDATIONS}

The processing of grilled fish had 12 events that pose a risk to food safety. Of the 12 risk events, there were 3 events that had the highest RPN, namely grilling method, draining 
method and storage method. These three events must be improved immediately to minimize or eliminate food safety risks so that grilled fish is safe for consumption.

The application of proper and correct production methods can minimize or prevent the occurrence of food safety risks for grilled fish. What should not be forgotten is always maintaining sanitation and hygiene before, during and after completing the processing process.

\section{REFERENCES}

4. Amir, N., Metusalach, M., \& Fahrul, F. (2018). Mutu dan Keamanan Pangan Produk Ikan Asap di Kabupaten Bulukumba Provinsi Sulawesi Selatan. Agrikan: Jurnal Agribisnis Perikanan, 11(2), 15. https://doi.org/10.29239/j.agrikan.11.2.15-21

5. Anggrahini, D., Karningsih, P. D. (2017). Manajemen Risiko Kualitas Pada Rantai Pasok Industri Pengolah Hasil laut Skala Menengah. Jurnal Sisfo, 06(03), 347-382 Sistem.

6. Ernawati, E. (2015). Analisis Risiko Operasional Dengan Metode Generalized Pareto Distibution Pada PT . Indo Bali di Tegalbadeng Barat Kabupaten Jembrana. (2).

7. Habibi, R. (2015). Analisis Risiko Sistem Rantai Dingin Perusahaan Fillet Ikan Beku Menggunakan metode FMEA. Tugas Akhir.

8. Hadiguna, R. A. (2013). Model Penilaian Risiko Berbasis Kinerja untuk Rantai Pasok Kelapa Sawit Berkelanjutan di Indonesia. Jurnal Teknik Industri, 14(1), 13-24. https://doi.org/10.9744/jti.14.1.13-24

9. Hariyadi, P. (2016). Tantanngan Ganda Keamanan Pangan di Indonesia: Peranan Rekayasa Proses Pangan. (January).

10. Kurniawan, W. (2017). Urgensi penerapan sistem jaminan keamanan perikanan. (November), 1-2.

11. M.Hanafi, M. (2014). Risiko, Proses Manajemen Risiko, dan Enterprise Risk Management. Management Research Review, 1-40. Retrieved from http://repository.ut.ac.id/4789/1/EKMA4262-M1.pdf

12. Pujawan, I. N., \& Geraldin, L. H. (2009). House of risk: A model for proactive supply chain risk management. Business Process Management Journal, 15(6), 953-967. https://doi.org/10.1108/14637150911003801

13. Purwaditya, A. K., Widodo, K. H. (2018). Mitigasi Risiko Pada Rantai Pasok Hulu Ikan Scombridae Segar di Pelabuhan Perikanan Pantai Tegal, Jawa Tengah. (1), 219-227.

14. Puspitasari, N. B., Arianie, G. P., \& Wicaksono, P. A. (2018). Analisis Identifikasi Masalah Dengan Menggunakan Metode Failure Mode And Effect Analysis (FMEA) Dan Risk Priority Number (RPN) Pada Sub Assembly Line (Studi Kasus: PT. Toyota Motor Manufacturing Indonesia). J@ti Undip: Jurnal Teknik Industri, 12(2), 77. https://doi.org/10.14710/jati.12.2.77-84

15. Riyadi, P. H., Bambang, A. N. (2007). Analisis kebijakan keamanan pangan produk hasil perikanan di pantura Jawa Tengah dan DIY. Jurnal Pasir Laut, 2, 30-39.

16. Suharjito, S., Marimin, M., Machfud, M., Haryanto, B., \& Sukardi, S. (2016). Identifikasi dan Evaluasi Risiko Manajemen Rantai Pasok Komoditas Jagung dengan Pendekatan Logika Fuzzy. Jurnal Manajemen Dan Organisasi, $1(2), \quad 118$. https://doi.org/10.29244/jmo.v1i2.14157

17. Suroso, E., Utomo, T. P., Hidayati, S., \& Nuraini, A. (2018). Pengasapan Ikan Kembung menggunakan Asap Cair dari Kayu Karet Hasil Redestilasi. Jurnal Pengolahan Hasil Perikanan Indonesia, 21(1), 42. https://doi.org/10.17844/jphpi.v21i1.21261

18. Swastawati, F., Surti, T., Agustini, T. W., \& Riyadi, P. H. (2009). Karakteristik Kualitas Ikan Asap yang diproses Menggunakan Metode dan Jenis Ikan Berbeda. (01), 1-7.

19. Thaheer, H., Hasibuan, S., \& Mumpuni, F. S. (2015). Model Resiko Keamanan Pangan Produk Pindang Pada UMKM Pengolahan Ikan Rakyat. Jurnal PASTI, 9(3), 275-285. Retrieved from http://publikasi.mercubuana.ac.id/index.php/pasti/article/view/491/432

20. Wahyuni, H. C., \& Sumarmi, W. (2018). Pengukuran Risiko Keamanan Pangan Pada Sistem Rantai Pasok Ikan Segar. J@ti Undip: Jurnal Teknik Industri, 13(1), 37. https://doi.org/10.14710/jati.13.1.37-44 